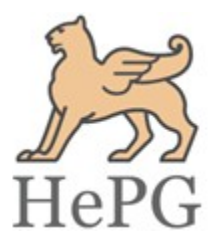

ISSN: 2348-1900

Plant Science Today

http://www.plantsciencetoday.online

Research Article

\title{
Mycorrhizal dependency and growth response of Gliricidia sepium (Jacq.) Kunth ex Walp. under saline condition
}

\section{Bhoopander Giri}

Department of Botany, Swami Shraddhanand College, University of Delhi, Delhi 110036, India

Article history

Received: 09 September 2017

Accepted: 30 September 2017

Published: 07 October 2017

(c) Giri B (2017)

Editor

K K Sabu

Publisher

Horizon e-Publishing Group

Correspondence

Bhoopander Giri

区hoopg@yahoo.com

\begin{abstract}
In pursuit of salinity-mycorrhiza interaction, a pot experiment was conducted to determine the dependence of Gliricidia sepium on arbuscular mycorrhizal association under salinity stress, which was imposed using different concentrations of sodium chloride solutions. The present study revealed that arbuscular mycorrhizal fungus; Rhizophagus fasciculatus significantly increased growth and biomass of G. sepium plants under saline condition. $G$. sepium showed a high degree of dependence on mycorrhizal symbiosis under saline as compared to non-saline condition. Under non-saline condition (SSO), G. sepium plants exhibited $23.9 \%$ dependence on $R$. fasciculatus, which increased with increase in the levels of salinity. At SS3 level, G. sepium plants showed 46.6\% mycorrhizal dependency followed by SS2 and SS1 levels of salinity. However, there was no significant difference between mycorrhizal dependency of G. sepium at SS1 and SS2 levels of salinity. Improved growth of $G$. sepium under salinity stress revealed $R$. fasciculatus a promising inoculant for the reclamation of degraded saline soils.
\end{abstract}

\section{Keywords}

soil salinity; arbuscular mycorrhiza; nutrition uptake; biomass production; waste land reclamation

\section{Citation}

Giri B. Mycorrhizal dependency and growth response of Gliricidia sepium (Jacq.) Kunth ex Walp. under saline condition. Plant Science Today 2017;4(4):154-160. doi: 10.14719/pst.2017.4.4.348

\section{Introduction}

Soil salinity has emerged as a significant threat to sustainable agriculture globally, as soluble salts under saline conditions adversely affect growth and development of plant (1). Salinization of soils has grown rapidly due to changing environmental conditions, which is covering about 800 million ha of the area (2). According to the Land and Plant Nutrition Management Services (FAO), more than $6 \%$ of the world's land is affected due to excessive accumulation of soluble salts (3). Indeed, soil microbes like arbuscular mycorrhizal fungi (AMF) are of great ecological significance as they develop symbiotic associations with the roots of more than $90 \%$ of terrestrial plant species $(4,5)$ and are considered promising candidates for sustainable agriculture (6). The extensive extraradical hyphae of AMF increase effective absorptive area of the roots and explore more soil volume (7); therefore, AMF enhance nutrient absorption and development of their partner plants. However, plants growing in saline soils could deprive of important nutrients 
like $\mathrm{P}$ as the phosphate ions get precipitated with the ions of other elements (8). Further, excessive salts in soil could induce osmotic, ionic, and oxidative stresses that severely affect plant growth. Several researchers have demonstrated that mycorrhizal fungi mitigate negative effects of salinity stress and promote plant growth (9-11).

Gliricidia sepium, a fast growing multipurpose leguminous plant, grow in many part of the world including South Asia, Central and Tropical Americas, West Indies, Mexico and West Africa and has been widely used in allay cropping systems, soil stabilization and as a green manure to improve soil fertility (12). Gliricidia sepium well adapts to the wide range of soil conditions viz., degraded wasteland, dry and infertile, acidic, calcareous, heavy clay and alkaline soils. Thus, determining growth response and mycorrhizal dependence of Gliricidia sepium under saline conditions could provide a practical solution to exploit mycorrhizal fungi for the reclamation of degraded salt-affected soils predominantly occurring throughout the world. Mycorrhizal dependency is a measurement of the degree of dependence of a plant on mycorrhizal association to produce its maximum growth or yield at the given level of soil fertility (13). To the best of our knowledge, there is no evidence available regarding dependence of Gliricidia sepium on AM symbiosis. Chasing salinity-mycorrhiza interaction and significance of AMF under saline condition, in this work, we report dependence and growth response of Gliricidia sepium on AMF, Rhizophagus fasciculatus (Thaxt.) C. Walker \& A. Schüßler.

\section{Materials and methods}

\section{Experimental design and biological materials}

A completely randomized design experiment was conducted with four levels of salinity viz., $(0,50$, $100,200 \mathrm{mM} \mathrm{NaCl}$ ) and two levels of mycorrhiza inoculation (uninoculated and inoculated with AMF). A total of eight treatments were carried out viz., Control (SS0), Mycorrhizal (SSO+M), $50 \mathrm{mM}$ $\mathrm{NaCl}$ (SS1), Mycorrhiza with $50 \mathrm{mM} \mathrm{NaCl}(\mathrm{SS} 1+\mathrm{M})$, $100 \mathrm{mM} \mathrm{NaCl}$ (SS2), Mycorrhiza with $100 \mathrm{mM} \mathrm{NaCl}$ (SS2+M), $200 \mathrm{mM} \mathrm{NaCl}$ (SS3), and Mycorrhiza with $200 \mathrm{mM} \mathrm{NaCl}(\mathrm{SS} 3+\mathrm{M})$. The salinity was imposed by irrigating with $50 \mathrm{ml}$ of $\mathrm{NaCl}$ solutions of respective concentrations once in a week. Plants were treated until the end of experiment. Control plants were irrigated with autoclaved distilled water. The soil-based inoculum of arbuscular mycorrhizal fungus, Rhizophagus fasciculatus was produced in the open pot soil culture using two (Trigonella foenum-graecum and Sorgham helepense) alternative trap plants (14). The roots of trap plants were chopped into small pieces and mixed with the rhizosphere soil to obtain a homogenous inoculum. Soil-based AMF inoculum containing about 100 fungal spore/10 $\mathrm{g}$ of soil along with chopped mycorrhiza-colonized roots (colonization $80 \%$ ) was applied as a layer below each seedling at the time of transplantation. The control plants were inoculated with nonmycorrhizal soil inoculum.

Before sowing, seeds of Gliricidia sepium were soaked in water overnight then disinfected using $5 \% \mathrm{NaOCl}$ solution for $15 \mathrm{~min}$ and germinated in the polythene bags filled with the mixture of sand and farmyard manure (ratio 1:1). After a week, five seedlings were transferred to each pot $(20-\mathrm{cm}$ height $\times 22-\mathrm{cm}$ diameter $)$ containing $2 \mathrm{~kg}$ of sandy loam soil (Table 1). Seedlings were later reduced to three per pot by manual thinning and allowed to grow under natural conditions. Soil extract was prepared according to Singh et al (15). Soil $\mathrm{pH}$ was determined with the help of $\mathrm{pH}$ meter and EC with electrical conductivity meter (Model LF 539, Germany). The determination of soil organic carbon was based on the Walkley and Black method (16), N on the Jackson's method (17), P on the Olsen's method (18) and K on an ammonium acetate method (19).

Table 1: Experimental soil physico-chemical properties

\begin{tabular}{lllllll}
\hline $\begin{array}{l}\text { Soil } \\
\text { texture }\end{array}$ & $\begin{array}{l}\text { Soil- } \\
\text { pH }\end{array}$ & EC-S/m & $\begin{array}{l}\text { Organi } \\
\text { c- C (\%) }\end{array}$ & N (\%) & $\begin{array}{l}\text { Availabl } \\
\text { e- K } \\
(\mathrm{mg} / \mathrm{Kg})\end{array}$ & $\begin{array}{l}\mathrm{P}- \\
(\mathrm{mg} / \mathrm{Kg})\end{array}$ \\
\hline $\begin{array}{l}\text { Sandy } \\
\text { loam }\end{array}$ & 7.6 & 0.12 & 1.1 & 0.58 & 65 & 49 \\
\hline
\end{tabular}

\section{Assessment of mycorrhizal root colonization}

The assessment of roots for AMF colonization was made at the end of the experiment by random sampling of plants, which were separated in to root and shoot. The roots were clarified with $\mathrm{KOH}$ and stained in trypan blue (20). Small root segments were observed under the light microscope to determine AMF structures. The extent of the root colonization and frequency of AMF structures (arbuscules, vesicles and intraradical hyphae) was determined (21).

\section{Analysis of plant growth, mycorrhizal dependency (MD) and phosphorus}

Plant growth performance was determined 45 and 90 days after germination (DAG) of Gliricidia sepium seedlings. Root and shoot length was measured with the help of measuring scale and dry biomass was determined after drying the plant tissues in an oven at $75^{\circ} \mathrm{C}$ for $72 \mathrm{~h}$ or till a constant weight was recorded. Oven-dried root and shoot tissues (90 DAG) were ground and sieved through a $0.5 \mathrm{~mm}$ sieve. Ground material $(0.2 \mathrm{~g})$ of dried shoot samples was analyzed for the $P$ concentration by digesting in an acid mixture of $\mathrm{HNO}_{3}$ and $\mathrm{HClO}_{4}(4: 1, \mathrm{v} / \mathrm{v})$. The resultant solution was diluted to a volume of $50 \mathrm{ml}$ with de-ionized water. The concentration of $\mathrm{P}$ was determined 
according to the molybdenum blue method (22) using UV spectrophotometer (Shimadzu UV-1601, Japan). Mycorrhizal dependency is a measurement of the degree to which a plant species is dependent on mycorrhizal condition to produce the highest growth at the given level of soil fertility (13), which was determined as per the formula of Plenchette et al (23).

\section{Statistical analysis}

Treatment effects were determined by one-way analysis of variance (ANOVA). The differences between treatments were confirmed by Duncan's Multiple Range Test (DMRT) (Cohort Berkeley, California). A significance level of $95 \%$ was applied.

\section{Results}

\section{Estimation of Rhizophagus fasciculatus} colonization in Gliricidia sepium roots

The present study showed that Rhizophagus fasciculatus successfully colonized Gliricidia sepium roots under saline condition (Fig 1a). Mycorrhizal roots showed presence of characteristic AM structure i.e. the inter-and intracellular hyphae, arbuscules, terminal and intercalary vesicles. Due to toxic effects of soluble salts, the degree of mycorrhizal colonization of Gliricidia sepium roots decreased as the levels of salinity increased. A maximum of $82 \%$ root colonization was recorded in case of mycorrhizainoculated plants, which decreased with increase in the levels of salinity. At SS1+M level of salinity, the mycorrhizal colonization of Gliricidia sepium roots decreased markedly. However, no traces of AMF were observed in case of nonmycorrhizal plants at any level of salinity. The mycorrhizal colonization of Gliricidia sepium roots decreased up to $50 \%$ at $\mathrm{SS} 3+\mathrm{M}(200 \mathrm{mM} \mathrm{NaCl})$ and $43 \%$ at $\mathrm{SS} 2+\mathrm{M}(100 \mathrm{mM} \mathrm{NaCl})$ as compared to the mycorrhizal colonization of control plants $(0 \mathrm{mM}$ $\mathrm{NaCl}$ condition).

\section{Growth response}

High concentration of $\mathrm{NaCl}$ decreased growth of Gliricidia sepium seedlings and showed a negative correlation between plant growth and increasing levels of salinity. Indeed, Rhizophagus fasciculatus exhibited profound effect as its inoculation significantly $(P<0.05)$ increased root and shoot length and dry biomass under saline condition (Fig 2). The maximum increase in root and shoot length was recorded in case of AMF inoculation under non saline condition, which decreased as the levels of salinity increased in both mycorrhizal and nonmycorrhizal plants. Root and shoot length and biomass accumulation drastically decreased at SS3 (200 mM NaCl) level of salinity in the case of nonmycorrhizal than mycorrhizal plants (Fig 2). Root and shoot length decreased about $40 \%$ and $42 \%$, and root and shoot biomass reduced up to
$53 \%$ and $43 \%$ respectively in uninoculated as compared to AMF-inoculated plants at SS3 level of salinity. Although highest inhibitory effect of salinity was recorded at SS3 level followed by SS2 level of salinity, salt-induced inhibition and its intensity significantly $(\mathrm{P}<0.05)$ reduced on mycorrhizal inoculation at each level of salinity. It was noteworthy that in mycorrhizal plants, root biomass accumulation at SS1 level of salinity (100 $\mathrm{mM} \mathrm{NaCl}$ ) supersedes even those which grow at sS0 level of salinity (non-saline).

\section{Nutrient acquisition}

In present study, the effect of $R$. fasciculatus was determined on $\mathrm{P}$ in both root and shoot tissues of Gliricidia sepium seedlings (Fig 3). The accumulation of $\mathrm{P}$ was greater in root than shoot tissues. Though excessive accumulation of soluble salts lessens availability of $\mathrm{P}$, mycorrhizal inoculation of Gliricidia sepium significantly $(\mathrm{P}<0.05)$ improved nutrient acquisition capacity of its partner plant as evidenced by the increased accumulation of $\mathrm{P}$ in both root and shoot tissues (Fig 3). At lower concentration, $\mathrm{NaCl}$ did not considerably affect uptake of P; however, as the concentration of $\mathrm{NaCl}$ increased in the soil, the accumulation of $\mathrm{P}$ decreased in both mycorrhizal and nonmycorrhizal plants. Instead, mycorrhizal plants had significantly higher concentrations of $\mathrm{P}$ than nonmycorrhizal plants.

\section{Relative mycorrhizal dependency}

The relative mycorrhizal dependency of Gliricidia sepium was determined by expressing the dry weights of mycorrhizal plants as a percentage of the dry weights of non-mycorrhizal plants (Fig 1b). The relative dependence of Gliricidia sepium on mycorrhizal fungus, $R$. fasciculatus changed with increasing levels of soil salinity. Gliricidia sepium plants showed significantly higher mycorrhizal dependency at SS3 level followed by the SS2 and SS1 levels of salinity. Inversely, mycorrhizal dependence of Gliricidia sepium plants on $R$. fasciculatus decreased under non-saline condition. However, there was no significant difference between mycorrhizal dependence of Gliricidia sepium between SS1 and SS2 levels of salinity.

\section{Discussion}

Salinization of soil is one of the major factors that restrict plant growth and makes them remain unproductive $(24,25)$. Though salinity exhibited inhibitory effects, inoculation of Gliricidia sepium seedlings with $R$. fasciculatus noticeably reduced injurious effects of salinity stress. In this study, we observed that the high concentration of $\mathrm{NaCl}$ was detrimental to both mycorrhiza and its host plant, affecting both fungal attributes and plant growth. Salinity had a negative impact on the mycorrhizal colonization of Gliricidia sepium, which is evidenced by the decreased colonization of 
Gliricidia sepium roots at increasing levels of salinity (Fig 1a). Our results corroborate previous findings that excessive soluble salts in the soil could restrict fungal hyphae growth and thereby reduce the extent of spreading mycorrhizal colonization (26). Improved plant growth on inoculation with $R$. fasciculatus indeed substantiate the fact that salinity merely impacts the effectiveness of mycorrhizal fungi, and the beneficial effects of mycorrhizal symbiosis on plant growth are likely to be independent of percent root colonization $(27,28)$.

Salinity-driven reduction in plant growth has been reported in several plant species such as Acacia auriculiformis (29), Sesbania aegyptiaca and Sesbania grandiflora (30), Acacia nilotica (31), Lotus glaber (32), Trifolium alexandrinum (33); Linum usitatissimum (34), Trigonella foenumgraecum (28) and Artemisia annua (10); however in all these cases mycorrhiza-inoculated plants performed better than uninoculated plants. The beneficial effect of mycorrhizal colonization on plant growth under saline condition has been documented as an impact of improved uptake of soil nutrients by mycorrhizal plants. Nonetheless, improved nutrient, particularly P and water status has often thought to be the major factors contributing to the increased growth of plants under salt stressed condition $(9,35)$. Increased uptake of $\mathrm{P}$ on inoculation of Gliricidia sepium seedlings with mycorrhizal fungus, $R$. fasciculatus is in agreement that the ability of mycorrhizal plant to absorb nutrients from the stressed soils is often greater than that of the non-mycorrhizal or control plants (Fig 3). In the present study, plant growth decreased with increase in the levels of salinity in both nonmycorrhizal and mycorrhizal plants, however the inoculation with $R$. fasciculatus attributed to significantly higher plant growth as compared to nonmycorrhizal plants at the equivalent levels of salinity. Increased plant growth in mycorrhizal plants suggested that mycorrhizal inoculant indeed supports its partner plant to combat environmental stresses like salinity and had restoration effect on salinityinduced damages to plants.

Janos (36) suggested mycorrhizal dependency as a measure of the benefit provided by mycorrhizal fungi that could depend on relative contribution of root and mycorrhiza-mediated nutrient supply to the plant. Examination of plant species in the natural ecosystems often shows a difference between intensity and consistency in the establishment of mycorrhizal colonization. Some plant species consistently have a high level of mycorrhizal colonization, some show moderate or intermediate, whilst a few species exhibit even no mycorrhizal formation in their roots $(36,37)$. Present study suggested that Gliricidia sepium was less dependent on AM symbiosis under non-saline condition; however its dependence on mycorrhizal fungi increased as the levels of salinity increased (Fig 1b), which is in agreement with the results of
Kumar et al (38) who revealed that mycorrhizal dependency of Jatropha increased $20.84 \%$ as the level of salinity increased from $0-0.4 \%$ and also with our previous findings that under degraded wasteland condition, mycorrhizal fungi increase uptake of mineral nutrients in Cassia siamea revealing that $C$. siamea has a high degree of dependence on mycorrhizal fungi for adequate supply of nutrients especially $\mathrm{P}$, to accomplish optimal growth $(39,40)$. In the present study, lower dependence of Gliricidia sepium plants under low or no saline condition may be owing to better availability and acquisition of soil nutrients. As the concentration of soluble salts in soil increased due to supply of $\mathrm{NaCl}$ solutions, the major nutrient like $P$ becomes unavailable to the plant as the phosphate ions get precipitate with other ions $(29,41)$. Therefore, under saline condition, to avail adequate amount of nutrients for achieving favorable growth, plants could seek assistance from its symbiotic partner to acquire nutrient from the soil through mycorrhizal hyphae (42). Mycorrhiza dependency has been found altered by a wide range of soil factors (42), stages of plant growth $(30,40)$ and plant and fungal species $(23,43)$. Giri et al. (44) demonstrated that under stress condition, mycorrhizal fungi first compete with the adverse effects of stress for their establishment and then they promote plant growth. Increased demand of mineral nutrients by plants is complemented by increase in mycorrhizal colonization of roots that gives rise to an increase in the mycorrhizal dependency at later stage of plant growth. Mycorrhizal dependency could decrease with increase in the level of available soil $\mathrm{P}$, because under such situation plant uptakes enough phosphate from the soil at its own (42). At extremely high soil P, the growth of nonmycorrhizal and mycorrhizal plants become either similar or growth of nonmycorrhizal plants exceeds over the mycorrhizal ones revealing that beyond a certain limit of available soil nutrient particularly P, a parasitic relationship could exist between mycorrhizal fungi and their host plants (45). Present study corroborates previous findings revealing that the availability of certain nutrients could alter mycorrhizal dependency of plant species and also supports the fact that mycorrhizal dependency differs with the soil conditions $(46,47)$. Present study demonstrates that salinity stress not only disturbs water potential but also makes the soil nutrient unavailable to plant; indeed mycorrhizal fungi attain rapid plant growth under saline condition; therefore, it may be of ecological importance inoculating seedlings with arbuscular mycorrhizal fungi under salt stress.

It is pertinent to conclude that Gliricidia sepium plants showed less mycorrhizal dependence under non-saline condition; however its dependence on AMF increased with increase in the levels of salinity. Salinity largely impacted plant growth and rendered plant stunted. However, improved growth of Gliricidia sepium 

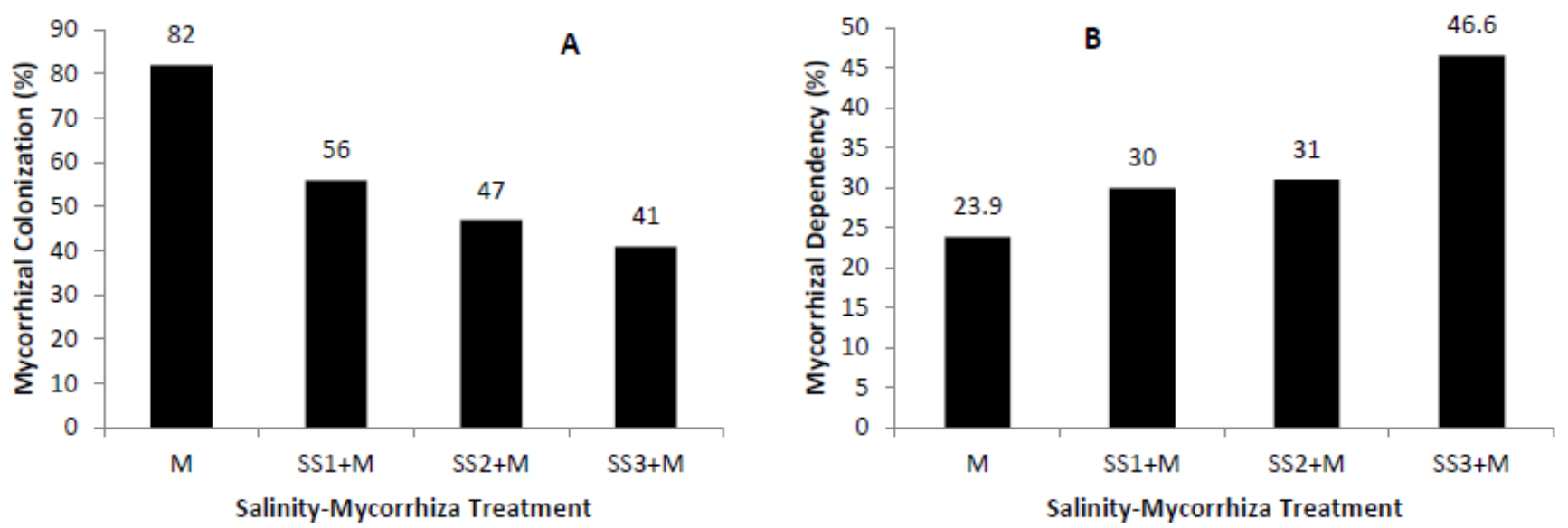

Fig. 1: Effect of salinity stress on mycorrhizal root colonization (A) and dependence (B) of Gliricidia sepium on Rhizophagus fasciculatus. Values are means of five replicates. Control (SS0), Mycorrhizal (SS0+M), $50 \mathrm{mM} \mathrm{NaCl}$ (SS1), Mycorrhiza with 50 $\mathrm{mM} \mathrm{NaCl}(\mathrm{SS} 1+\mathrm{M}), 100 \mathrm{mM} \mathrm{NaCl}$ (SS2), Mycorrhiza with $100 \mathrm{mM} \mathrm{NaCl}(\mathrm{SS} 2+\mathrm{M}), 200 \mathrm{mM} \mathrm{NaCl}$ (SS3), and Mycorrhiza with $200 \mathrm{mM} \mathrm{NaCl}(\mathrm{SS} 3+\mathrm{M})$.
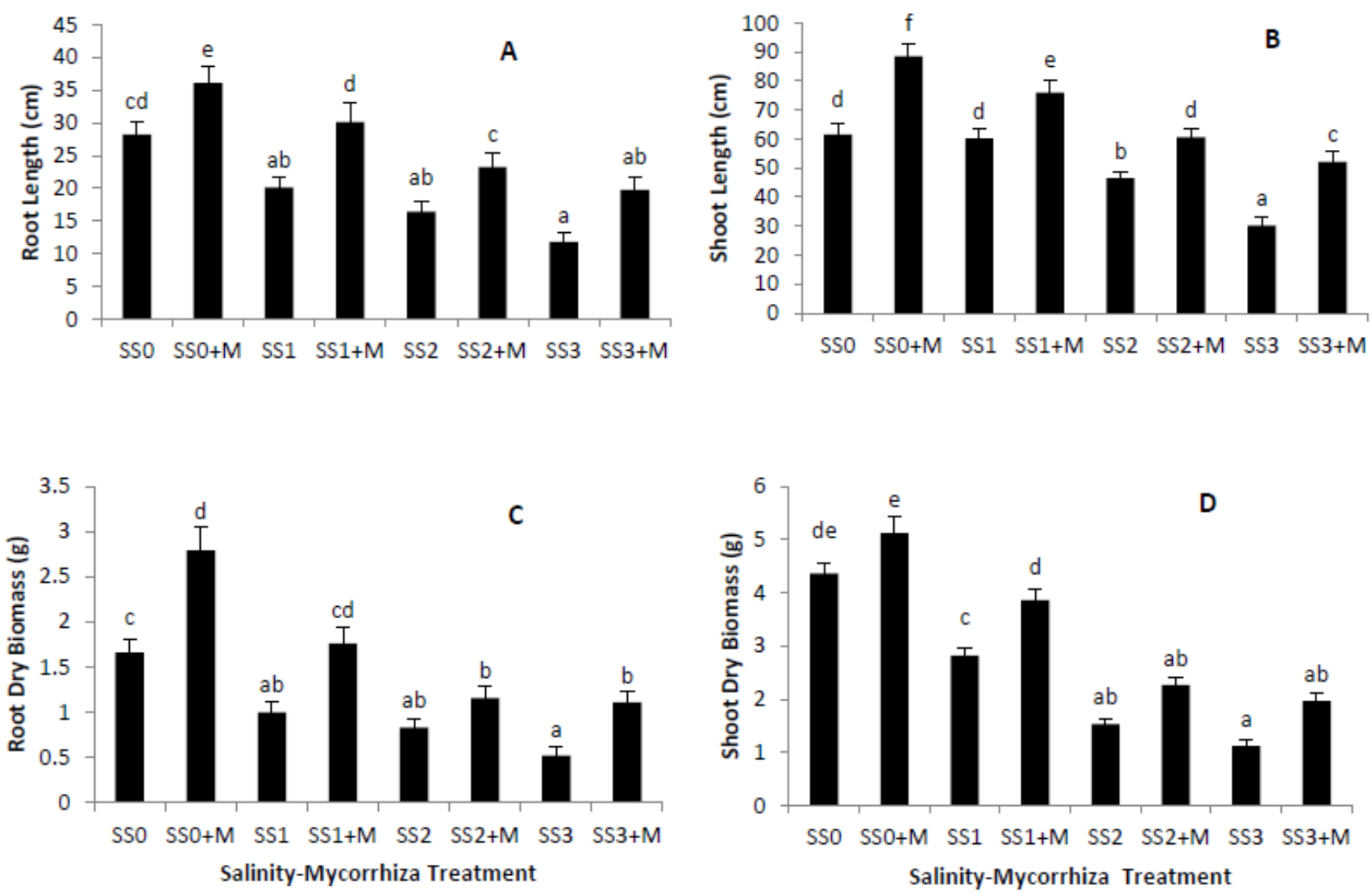

Fig. 2: Effect of salinity and Rhizophagus fasciculatus inoculation on root (A) and shoot (B) length and root (C) and shoot (D) biomass of mycorrhizal and nonmycorrhizal plants of Gliricidia sepium 90 DAG. Values are means of five replicates and different letters at the top of bars indicate significant differences at $\mathrm{P}<0.05, \pm \mathrm{SD}$. DAG-days after germination. Control (SS0), Mycorrhizal (SS0+M), $50 \mathrm{mM} \mathrm{NaCl}$ (SS1), Mycorrhiza with $50 \mathrm{mM} \mathrm{NaCl}(\mathrm{SS} 1+\mathrm{M}), 100 \mathrm{mM} \mathrm{NaCl}$ (SS2), Mycorrhiza with $100 \mathrm{mM} \mathrm{NaCl}(\mathrm{SS} 2+\mathrm{M}), 200 \mathrm{mM} \mathrm{NaCl}$ (SS3), and Mycorrhiza with $200 \mathrm{mM} \mathrm{NaCl}(\mathrm{SS} 3+\mathrm{M})$.

evidenced that deleterious effects of salinity can be impaired with Rhizophagus fasciculatus inoculation. This study substantiated the fact that AMF could be the potential candidate for efficient utilization of degraded wastelands and saline-and sodic soils largely occurring throughout the world.

\section{Acknowledgements}

The author wishes to express sincere thanks to $\mathrm{Dr}$ Bhawna Saxena for providing technical help and Abhinav Goswami for statistical analysis suggestions during the preparation of manuscript.

Conflict of interest: BG has no conflict of interest. 

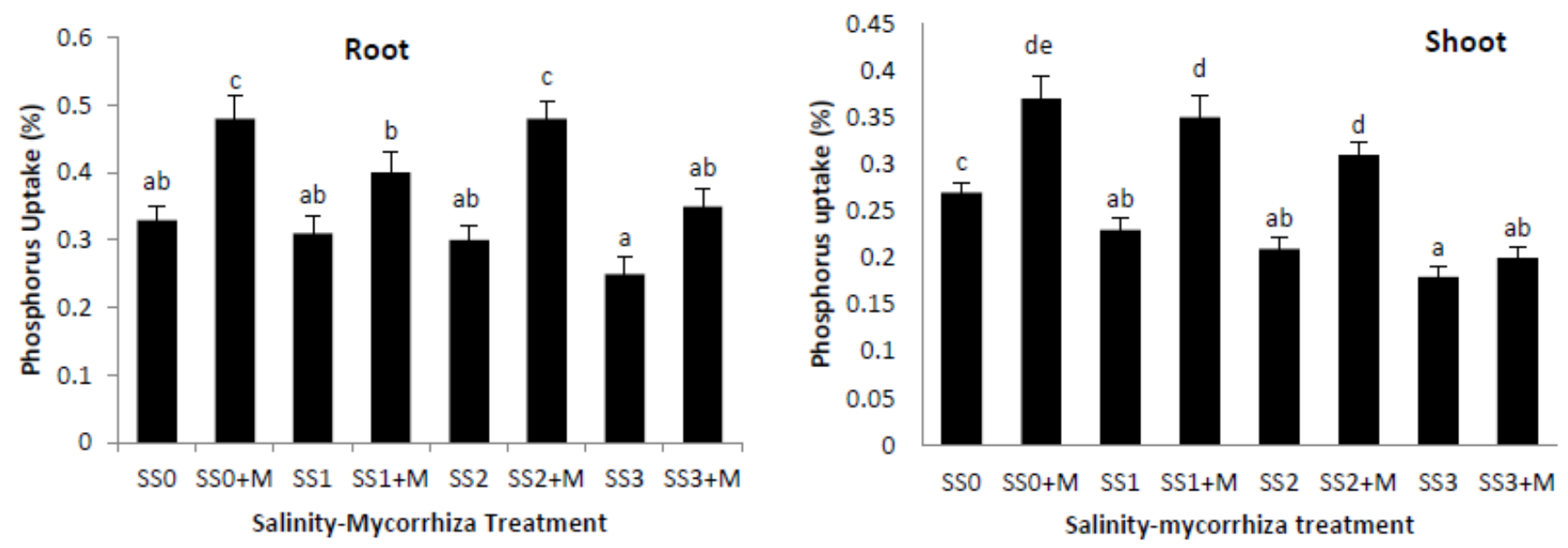

Fig. 3: Effect of salinity and Rhizophagus fasciculatus inoculation on $\mathrm{P}$ in the root and shoot tissues of mycorrhizal and nonmycorrhizal plants of Gliricidia sepium 90 DAG. Values are means of five replicates and different letters at the top of bars indicate significant differences at $\mathrm{P}<0.05, \pm \mathrm{SD}$. DAG-days after germination. Control (SS0), Mycorrhizal (SS0+M), 50 $\mathrm{mM} \mathrm{NaCl}$ (SS1), Mycorrhiza with $50 \mathrm{mM} \mathrm{NaCl}$ (SS1+M), $100 \mathrm{mM} \mathrm{NaCl}$ (SS2), Mycorrhiza with $100 \mathrm{mM} \mathrm{NaCl}$ (SS2+M), $200 \mathrm{mM}$ $\mathrm{NaCl}$ (SS3), and Mycorrhiza with $200 \mathrm{mM} \mathrm{NaCl}(\mathrm{SS} 3+\mathrm{M})$.

\section{References}

1. Elhindi KM, El-Din AS, Abdallah M, Elgorban AM. The impact of arbuscular mycorrhizal fungi in mitigating salt-induced adverse effects in sweet basil (Ocimum basilicum L.). Saudi Journal of Biological Sciences 2017; 24: 170-9. https://doi.org/10.1016/j.sjbs.2016.02.010

2. Singh YP. Sustainable reclamation of sodic soils: farmer's participatory approaches. In: Gupta SK, Goyal MR, editors. Soil Salinity management in agriculture: technological advances and applications. CRC press, Taylor and Francis; 2017.p. 289-313.

3. Gupta SK, Goyal MR, editors. Soil Salinity management in agriculture: technological advances and applications. CRC press, Taylor and Francis; 2017.

4. Gadkar V, David-Schwartz R, Kunik T, Kapulnik Y. Arbuscular mycorrhizal fungal colonization. Factors involved in host recognition. Plant Physiol. 2001; 127: 1493-9. https://doi.org/10.1104/pp.010783

5. Gomes SIF, Merckx VSFT, Saavedra S. Fungal-host diversity among myco-heterotrophic plants increases proportionally to their fungal-host overlap. Ecology and Evolution 2017; 10: 3623-30. https://doi.org/10.1002/ece3.2974

6. Bender SFC, van der Heijden MG. An underground revolution: biodiversity and soil ecological engineering for agricultural Sustainability. Trends $\begin{array}{lll}\text { Ecol } & \text { Evol. 2016; } & \text { 31(6):440-52. }\end{array}$ https://doi.org/10.1016/j.tree.2016.02.016

7. Smith SE, and Read DJ. Mycorrhizal Symbiosis. Academic Press; 2008.

8. Azcon-Aguiler C, Azcon R, Barea JM. Endomycorrhizal fungi and Rhizobium as biological fertilizers for Medicago sativa in normal cultivation. Nature 1979; 279:325-7. https://doi.org/10.1038/279325a0

9. Ruiz-Lozano JM, Porcel R, Azcón C, Aroca R. Regulation by arbuscular mycorrhizae of the integrated physiological response to salinity in plants: new challenges in physiological and molecular studies. J Exp $\quad$ Bot. 2012; 63:403344. https://doi.org/10.1093/jxb/ers126

10. Li L, Zhang H, Zhang L, Zhou Y, Yang R, Ding C et al. The physiological response of Artemisia annua L. to salt stress and salicylic acid treatment. Physiol Mol
Biol
Plants
2014;
20(2):161-9.
https://doi.org/10.1007/s12298-014-0228-4

11. Ebrahim $\mathrm{MKH}$, Saleem A. Alleviating salt stress in tomato inoculated with mycorrhizae: photosynthetic performance and enzymatic antioxidants, J. Taibah Univ Sci. (in press) 2017; http://dx.doi.org/10.1016/j.jtusci.2017.02.002

12. Okon IE, Osonubi O, and Sangingav N. Vesiculararbuscular mycorrhiza effects on Gliricidia sepium and Senna siamea in a fallowed alley cropping system. Agroforestry Systems 1996; 33: 165-75. https://doi.org/10.1007/BF00213648

13. Gerdemann JW. Vesicular-arbuscular mycorrhiza. In: Torrey JG, Clarkson DT editors. The Development and Function of Roots, Academic Press, London;1975.p. 575-92.

14. Kapoor R, Giri B, Mukerji KG. Mycorrhization of coriander to enhance the concentration and quality of oil in seeds. J Sci Food Agric. 2002; 82:1-4.

15. Singh D, Chhonkar PK, Pandey RN. Soil plant water analysis: a methods manual. Division of Soil Science and Agriculture Chemistry, Indian Institute of Agricultural Research, New Delhi; 2001.

16. Walkley A, Black IA. An examination of Degtjareff method for determining soil organic matter and a proposed modification of the chromic acid titration method. Soil Sci. 1934; 37: 29-37. https://doi.org/10.1097/00010694-193401000-00003

17. Jackson ML. Soil chemical analysis. Prentice Hall of India Pvt, New Delhi; 1962.

18. Olsen SR, Cole CV, Watanabe FS, Dean LA. Estimation of available phosphorus in soils by extraction with sodium bicarbonate. (Circular of the US Department of Agriculture 939) USDA, Washington, D.C; 1954.

19. Hanway JJ, Heidel H. Soil analysis methods as used in Iowa state college soil testing laboratory. Iowa Agric. 1952; 57:1-31.

20. Philips J, Hayman DS. Improved procedure for cleaning roots and staining parasitic and vesiculararbuscular mycorrhizal fungi for rapid assessment of infection. Trans Br Mycol Soc. 1970; 55:158-61. https://doi.org/10.1016/S0007-1536(70)80110-3

21. Giovannetti M, Mosse B. An evaluation of techniques for measuring vesicular arbuscular mycorrhizal 
infection in roots. New Phytol. 1980; 84:489-500. https://doi.org/10.1111/j.1469-8137.1980.tb04556.x

22. Allen SE. Chemical analysis of ecological materials, 2nd edn. Blackwell Scientific Publications, London; 1989.

23. Plenchette C, Fortm JA, Furlan V. Growth response of several plant species to mycorrhizae in a soil of moderate $\mathrm{P}$ fertility. I. Mycorrhizal dependency under field conditions. Plant Soil 1983; 70: 199- 209. https://doi.org/10.1007/BF02374780

24. Santander C, Aroca R, Ruiz-Lozano JM, Olave J, Cartes P, Borie F et al. Arbuscular mycorrhiza effects on plant performance under osmotic stress. Mycorrhiza 2017; 27:639-57. https://doi.org/10.1007/s00572-017-0784-x

25. Saxena B, Shukla K, Giri B. Arbuscular mycorrhizal fungi and tolerance of salt stress in plants. In: Wu QS, editor. Arbuscular mycorrhizas and stress tolerance of plants. Springer Nature Singapore; 2017.p.67-98. https://doi.org/10.1007/978-981-104115-0_4

26. McMillen B, Juniper S, Abbott LK. Inhibition of hyphal growth of a vesicular-arbuscular mycorrhizal fungus in soil containing sodium chloride limits the spread of infection from spores. Soil Biol. Biochem. 1998; 30:1639-46. https://doi.org/10.1016/S0038-0717(97)00204-6

27. Jahromi F, Aroca R, Porcel R, Ruiz-Lozano JM. Influence of salinity on the in vitro development of Glomus intraradices and on the in vivo physiological and molecular responses of mycorrhizal lettuce plants. Microbial Ecology 2008; 55:45-53. https://doi.org/10.1007/s00248-007-9249-7

28. Evelin H, Giri B, Kapoor R. Contribution of Glomus intraradicesinoculation to nutrient acquisition and mitigation of ionic imbalance in NaCl-stressed Trigonella foenum-graecum. Mycorrhiza 2012; 22:203-17. https://doi.org/10.1007/s00572-011-0392-0

29. Giri B, Kapoor R, Mukerji KG. Influence of arbuscular mycorrhizal fungi and salinity on growth, biomass and mineral nutrition of Acacia auriculiformis. Biol Fertil Soils 2003; 38:170-5 https://doi.org/10.1007/s00374-003-0636-z

30. Giri B, Mukerji KG. Mycorrhizal inoculant alleviates salt stress in Sesbania aegyptiaca and Sesbania grandiflora under field conditions: evidence for reduced sodium and improved magnesium uptake. Mycorrhiza 2004; 14:307-12. https://doi.org/10.1007/s00572-003-0274-1

31. Giri B, Kapoor R, Mukerji KG. Improved tolerance of Acacia nilotica to salt stress by arbuscular mycorrhiza, Glomus fasciculatum may be partly related to elevated $\mathrm{K}+/ \mathrm{Na}+$ ratios in root and shoot tissues. Microbial Ecology 2007; 54:753-760. https://doi.org/10.1007/s00248-007-9239-9

32. Sannazzaro AI, Echeverria M, Alberto EO, Ruiz OA, Menendez AB. Modulation of polyamine balance in Lotus glaber by salinity and arbuscular mycorrhiza. Plant Physiol Biochem. 2007; 45:39-46. https://doi.org/10.1016/j.plaphy.2006.12.008

33. Shokri S, Maadi B. Effect of arbuscular mycorrhizal fungus on the mineral nutrition and yield of Trifolium alexandrinum plants under salinity stress. J Agron. 2009; 8:79-83. https://doi.org/10.3923/ja.2009.79.83
34. Khan MN, Siddiqui MH, Mohammad F, Naeem M, Khan MMA. Calcium chloride and gibberellic acid protect linseed (Linum usitatissimum L.) from $\mathrm{NaCl}$ stress by inducing antioxidative defence system and osmoprotectant accumulation. Acta Physiol Plant. 2010; 32:121-32. https://doi.org/10.1007/s11738-0090387-z

35. Evelin H, Kapoor R, Giri B. Arbuscular mycorrhizal fungi in alleviation of salt stress: a review. Ann Bot.2009; 104:1263-81. https://doi.org/10.1093/aob/mcp251

36. Janos DP. Vesicular-arbuscular mycorrhizae affect lowland tropical rain forest plant growth. Ecology 1980; 61: 151-62. https://doi.org/10.2307/1937165

37. Brundrett MC, Kendrick B. The mycorrhizal status, root anatomy, and phenology of plants in a sugar maple forest. Can J Bot. 1988; 66: 1153-73. https://doi.org/10.1139/b88-166

38. Kumar A, Sharma S, Mishra S. Influence of arbuscular mycorrhizal (AM) fungi and salinity on seedling growth, solute accumulation and mycorrhizal dependency of Jatropha curcas L. J Plant Growth Regul. 2010; 29: 297-306. https://doi.org/10.1007/s00344-009-9136-1

39. Diaz G, Azcon-Aguilar C, Honrubia M. Influence of arbuscular mycorrhiza on heavy metals ( $\mathrm{Zn}$ and $\mathrm{Pb}$ ) uptake and growth of Lygeum spartum and Anthyllis cytisoides. Plant Soil 1996; 180: 241-49. https://doi.org/10.1007/BF00015307

40. Giri B, Kapoor R, Mukerji KG. Effect of the arbuscular mycorrhizae Glomus fasciculatum and $G$. macrocarpum on the growth and nutrient content of Cassia siamea in a semi-arid Indian wasteland soil. New Forests 2005; 29:63-73. https://doi.org/10.1007/s11056-004-4689-0

41. Al-Karaki GN, Hammad R, Rusan M. Response of two tomato cultivars differing in salt tolerance to inoculation with mycorrhizal fungi under salt stress. Mycorrhiza 2001; 11:43-47. https://doi.org/10.1007/s005720100098

42. Tawaraya K. Arbuscular mycorrhizal dependency of different plant species and cultivars. Soil Science and Plant Nutrition 2003; 49(5): 655-68. https://doi.org/10.1080/00380768.2003.10410323

43. Graham JH, Eissenstat DM. Host genotype and the formation and function of VA mycorrhizae. Plant Soil 1994; 159:179-85. https://doi.org/10.1007/BF00000107

44. Giri B, Kapoor R, Agarwal L, Mukerji KG. Preinoculation with arbuscular mycorrhizae helps Acacia auriculiformis grow in degraded Indian wasteland soil. Comm Soil Sci Plant Anal. 2004; 35:193-204. https://doi.org/10.1081/CSS-120027643

45. Bethlenfalvay GJ, Bayne HG, Pacovsky S. Parasitic and mutualistic associations between a mycorrhizal fungus and soybean: The effect of phosphorus on host plant endophyte interactions. Physiol Plant. 1983; 57: 543-48. https://doi.org/10.1111/j.1399-3054.1983.tb02783.x

46. Menge JA, Johnson ELV, Platt RG. Mycorrhizal dependency of several citrus cultivars under three nutrient regimes. New Phytol.1978; 81: 553-60. https://doi.org/10.1111/j.1469-8137.1978.tb01628.x

47. Giri B,Kapoor R, Mukerji KG. Sesbania aegypatiaca Pers seedling response to VA mycorrhization in two types of soil. Phytomorphology 2000; 50: 327 